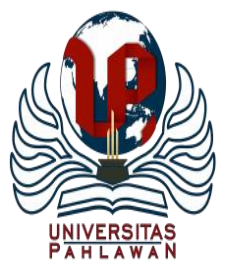

Edukatif : Jurnal Ilmu Pendidikan Volume 3 Nomor 3 Tahun 2021 Halm 785 - 793

EDUKATIF: JURNAL ILMU PENDIDIKAN

Research \& Learning in Education

https:/ledukatif.org/index.php/edukatif/index

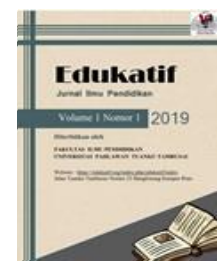

\title{
Pengembangan Multimedia Interaktif Menggunakan Software Macromedia Flash 8 Sebagai Upaya Meningkatkan Motivasi Belajar Siswa Sekolah Dasar
}

\author{
Rahmad Wahyugi ${ }^{1 凶}$, Fatmariza $^{2}$ \\ Universitas Negeri Padang ${ }^{1,2}$ \\ E-mail : $\underline{\text { rahmad.wahyugi12@ gmail.com }}^{1}$, fatmariza@ fis.unp.ac.id $^{2}$
}

\begin{abstract}
Abstrak
Penelitian di latarbelakangi oleh belum adanya media pembelajaran yang dapat meningkatkan motivasi belajar siswa serta yang sesuai dengan karakteristik perkembangan siswa dan karakteristik era revolusi industri 4.0. Tujuan penelitian ini adalah untuk mengembangkan multimedia interaktif dalam meningkatkan motivasi belajar siswa sekolah dasar yang valid, praktis dan efektif. Penelitian ini merupakan penelitian pengembangan dengan menggunakan model ADDIE. Model ADDIE terdiri dari 5 tahapan yaitu tahapan analisis, perancangan, pengembangan, penerapan dan evaluasi. Hasil penelitian dinyatakan bahwa telah dikembangkannya multimedia interaktif menggunakan software macromedia flash 8 sebagai upaya meningkatkan motivasi belajar siswa sekolah dasar yang valid, praktis dan efektif. Implikasi penelitian ini dapat dijadikan sebagai referensi oleh praktisi pendidikan untuk dapat meningkatkan motivasi belajar siswa.
\end{abstract}

Kata Kunci: multimedia interaktif, macromedia, motivasi.

\begin{abstract}
This research was based on the absence of learning media that can increase students' learning motivation and are in accordance with the characteristics of students' development and the characteristics of the era of the industrial revolution 4.0. The purpose of this research is to develop interactive multimedia that is valid, practical and effective in increasing elementary school students' learning motivation. This research was a development research using the ADDIE model. The ADDIE model consists of 5 stages, namely the stages of analysis, design, development, implementation and evaluation. The results of the study indicate that interactive multimedia using Macromedia Flash 8 software was developed as an effort to increase students' learning motivation in elementary schools which was valid, practical and effective. The implication of this research can be used as a reference by educational practitioners to increase students' learning motivation.
\end{abstract}

Keywords: interactive multimedia, macromedia, motivation.

Copyright (c) 2021 Rahmad Wahyugi, Fatmariza

$\triangle$ Corresponding author

Email : rahmad.wahyugi12@gmail.com

DOI : https://doi.org/10.31004/edukatif.v3i3.439

ISSN 2656-8063 (Media Cetak)

ISSN 2656-8071 (Media Online)

Edukatif : Jurnal Ilmu Pendidikan Vol 3 No 3 Tahun 2021

p-ISSN 2656-8063 e-ISSN 2656-8071 


\section{PENDAHULUAN}

Perkembangan teknologi telah melingkupi semua sistem kehidupan manusia termasuk pada sistem pendidikan, (Kenedi et al, 2019). Penggunaan teknologi pada sistem pendidikan sangat membantu proses pengelolaan pendidikan. Salah satu penggunaan teknologi pada sistem pendidikan adalah pada pelaksanaan proses pembelajaran di sekolah,(Helsa et al, 2019). Penggunaan teknologi pada proses pembelajaran merupakan hal yang sangat penting untuk dilaksanakan dikarenakan perkembangan era revolusi industri 4.0 yang menuntut pemanfaatan dan pengembangan teknologi pada setiap aspek kehidupan termasuk pada proses pembelajaran. Era revolusi industri 4.0 menuntut adanya pengunaan teknologi dalam proses pembelajaran dikarenakan adanya tantangan yang harus di capai dalam proses pembelajaran yaitu sistem pendidikan harus mampu menghasilkan lulusan yang memiliki berbagai macam keterampilan dengan dilandasi penguasaan teknologi, (Helsa and Kendi, 2019). Hal ini dikarenakan pada masa yang akan datang lulusan akan menghadapi permasalahan yang lebih komplek yang membutuhkan penguasaan teknologi dalam proses pemecahan masalah. Oleh sebab itu diperlukanya integrasi penggunaan teknologi dalam proses pembelajaran.

Pengunaan teknologi pada proses pembelajaran memiliki dampak yang baik terhadap kualitas pembelajaran. (Hicks, 2011) Banyak penelitian yang menyatakan bahwa penggunaan teknologi dalam proses pembelajaran dapat meningkatkan hasil belajar siswa, (Lee et al, 2011; Gadburry-Amyot et al, 2013, Naik et al, 2020). Selain itu juga penggunaan teknologi dapat meningkatkan berbagai kemampuan berpikir siswa seperti kemampuan berpikir kritis, kreatif dan kemampuan berpikir tingkat tinggi siswa, (Barata et al, 2013; Pucer et al, 2014). Maka dari hasil penelitian ini dapat disimpulkan bahwa penggunaan teknologi dalam proses pembelajaran dapat meningkatkan kualitas pembelajaran sehingga guru dituntut untuk dapat melaksanakannya. Guru bertanggung jawab untuk dapat mendesaian proses pembelajaran yang memadukan teknologi didalamnya. Diperlukan kreativitas guru dalam merancang pembelajaran sehingga diciptakannya suasana pembelajaran yang inovatif, kreatif, aktif serta dapat memotivasi siswa dalam belajar dengan mamaksimalkan teknologi.

Salah satu penggunaan teknologi yang dapat diterapkan dalam proses pembelajaran adalan dengan mengambangkan media pembelajaran. Media pembelajaran merupakan alat yang digunakan oeh guru untuk mempermudah siswa memahami pembelajaran, (Helsa et al, 2019). Media pembelajaran sangat penting digunakan dalam proses pembelajaran. Termasuk pada proses pembelajaran di sekolah dasar. Siswa sekolah dasar merupakan anak yang berada pada masa operasional kongret, (Kiswanto, 2017, Pratiwi et al, 2020). Pada masa ini anak belajar dari benda-benda nyata maupun pengalaman langsung siswa. Sehingga guru harus mampu menyajikan benda-benda nyata dan mengaitkan pengalaman siswa dengan pembelajaran yang akan dilaksanakan. Namun kendala yang sering dihadapi adalah ketidakmampuan semua guru untuk menghadirkan benda-benda nyata kedalam proses pembelajaran. Maka diperlukan lah media pembelajaran sebagai alat manipulaitif untuk menjelaskan suatu konsep kepada siswa. Oleh sebab itu guru bertanggung jawab untuk dapat mengembangkan media pembelajaran yang sesuai dengan tingkat perkembangan siswa.

Namun berdasarkan observasi yang peneliti lakukan di SDN di Kecamatan Palembayan Kabupaten Agam ditemukan bahwa guru tidak menggunakan media pembelajaran pada saar proses pembelajaran. Guru hanya menjelaskan materi secara konvensional saja. Hal ini mengakibatkan siswa hanya mendengarkan penyampaian materi yang disampaikan oleh guru. Siswa terlihat tidak tertarik dengan materi yang disajikan oleh guru, bahkan beberapa siswa terlihat bosan ketika guru menyajikan materi. Pada saat guru memberikan tugas terlihat siswa tidak serius mengerjakannya. Siswa mengeluh mengerjakan tugas yang diberikan. Bahkan siswa berusaha mencontek hasil kerja temannya. Berdasarkan analisis peneliti terhadap hasil obervasi tersebut ditemukan permasalahan yaitu guru tidak menggunakan media pembelajaran yang sesuai dengan perkembangan siswa sehingga berakibatkan kepada rendahnya motivasi belajar siswa. Hasil analisis ini juga 
787 Pengembangan Multimedia Interaktif Menggunakan Software Macromedia Flash 8 Sebagai Upaya Meningkatkan Motivasi Belajar Siswa Sekolah Dasar - Rahmad Wahyugi, Fatmariza

DOI: https://doi.org/10.31004/edukatif.v3i3.439

diperkuat oleh hasil penyebaran angket siswa mengenai motivasi belajar. Dari hasil tersebut didapatkan skor rata-rata siswa yaitu 54 dengan kategori rendah.

Motivasi belajar merupakan dorongan yang ada didalam diri yang menimbulkan adanya rasa ingin untuk belajar, (Lin et a, 2017; Pratama et al, 2019). Motivasi belajar dapat dilihat dari tekun nya siswa dalam pembelajaran, ulet, tertarik dengan berbagai permasalahan, menyenangi pekerjaan secara mandiri, dan aktif mengemukakan pendapat, (Suhana, 2012). Dari permasalahan yang dihadapi oleh guru dalam pembelajaran tersebut dapat di indikasikan bahwa rendahnya motivasi belajar siswa. Oleh sebab itu perlunya solusi permasalahan yang dapat mengatasi permasalahan tersebut.

Berdasarkan diskusi peneliti maka solusi yang tepat untuk mengatasi permasalahan tersebut adalah dengan mengembangkan media pembelajaran yang dapat meningkatkan motivasi belajar siswa. Media pembelajaran yang dikembangkan disesuaikan dengan perkembangan siswa dan karakteristik era revolusi industri 4.0. Maka berdasarkan kesepakatan media pembelajaran yang dikembangkan yaitu multimedia interaktif menggunakan software macromedia flash 8. Multimedia interaktif merupakan bentuk dari penggunaan teknologi yang mampu menyajikan informasi secara interaktif dengan bantuan laptop maupun smartphone. Sehingga dengan dikembangkannya multimedia ini dapat memadukan penggunaan teknologi dalam proses pembelajaran. Selama ini banyak penelitian yang berhubungan dengan pengembangan media. Media yang dikembangkan masih bersifat tradisional tanpa menggabungkan unsur teknologi didalamnya. Maka peneliti tertarik untuk melakukan pengembangan media pembelajaran dengan memadukan unsur teknologi didalam proses pembelajaran. Oleh sebab itu tujuan dari penelitian ini adalah untuk mengembangkan multimedia interaktif dalam meningkatkan motivasi belajar siswa sekolah dasar yang valid, praktis dan efektif.

Penelitian ini didukung oleh penelitian sebelumnya yang telah mengembangkan media pembelajaran dengan menggunakan permainan ular tangga untuk sekolah dasar. Hasil penelitian dinyatakan bahwa media yang dikembangkan dapat meningkatkan hasil belajar siswa, (Afandi, 2018). Penelitian lainnya juga menyatakan bahwa telah dikembangkannya media pembelajaran adaptif yang dapat meningkatkan hasil belajar siswa, (Batubara and Ariani, 2019). Selain itu penelitian lainya juga menyatakan bahwa telah dikembangkannya media pembelajaran berbasis literasi sains untuk siswa sekolah dasar dalam upaya meningkatkan kemampuan literasi sains siswa sekolah dasar, (Azimi et al, 2017). Dari hasil penelitian terdahulu tersebut dapat dilihat bahwa belum adanya pengembangan media pembelajaran yang menggabungkan unsur teknologi dalam proses pembelajaran disekolah dasar. Selain itu pengembangan multimedia ini bertujuan untuk meningkatkan motivasi belajar siswa.

Penelitian ini penting dilaksanakan dikarenakan perlunya penyesuaian pembelajaran disekolah dasar yang sesuai dengan tuntutan era revolusi industri 4.0 dengan pemanfaaatan teknologi dalam pembelajaran. Selain itu perlunya peningkatan motivasi belajar siswa agar kualitas pembelajaran disekolah dapat mencapai tujuan pembelajaran yang telah ditetapkan.

\section{METODE PENELITIAN}

Penelitian ini merupakan penelitian pengembangan dengan menggunakan model ADDIE. Model ADDIE terdiri dari 5 tahapan yaitu tahapan analisis, perancangan, pengembangan, penerapan dan evaluasi. Pada tahap analisis dialkukan analisis kurikulum dan analisis kebutuhan. Pada tahapan perancanngan dilakukan membuat flowchart dan story board multimedia interaktif. Pada tahapan pengembangan dilakuan pengembangan multimedia interaktif, instrumen penilaian dan angket, validasi produk dan perevisian. Pada tahapan implementasi dilakukan uji coba multimedia interaktif untuk mengetahui praktikalitas dan efektivitas multimedia. Pada tahap evaluasi dilakukan penyempurnaan multimedia interaktif. Teknik pengumpulan data menggunakan kuisioner untuk uji validitas, praktikalitas dan efektivitas. Teknik analisis data dilakukan 
dengan melakukan perhitungan persentasi hasil validitas, praktikalitas dan efektivitas kemudian di konversikan pada masing-masing kriteria.

\section{HASIL DAN PEMBAHASAN PENELITIAN}

Temuan penelitian akan dibahas melalui tahapan penelitian yang dimulai dari tahapan analisis. Tahapan analisis bertujuan untuk mengetahui kebutuhan pengembangan dan materi apa yang akan dikembangkan. Adapun kegiatan yang dilakukan pada tahapan pengembangan ini adalah melakukan analisis kebutuhan dan analisis kurikulum. Pada analisis kebutuhan dikaji bahwa perkembangaan era revolusi industri 4.0 berdampak kepada setiap elemen kehidupan termasuk pada sistem pendidikan, (Kenedi et al, 2019). Era revolusi industri 4.0 menuntut sistem pendidikan untuk dapat mengembangkan proses pembelajaran berbasis teknologi, (Hamimah, 2019). Salah satu bentuk pengembangan teknologi dalam proses pembelajaran dapat dikembangkan melalui media pembelajaran. Adanya permasalahan pembelajaran yang dilaksanakan oleh guru yang berhubungan dengan tidak digunakannya media pembelajaran pada proses pembelajaran mengakibatkan rendahnya motivasi belajar siswa.

Pembelajaran disekolah dasar harus menggunakan media pembelajaran dikarenakan siswa sekolah dasar berada pada masa operasional kongkret. Pada masa ini siswa harus belajar dari benda-benda nyata sehingga guru harus mampu menyajikan benda nyata atau benda yang bersifat manipulatif agar siswa dapat memahami materi pembelajaran, (Mansur et al, 2017) Selain itu ditemukan juga rendahnya motivasi belajar siswa. Motivasi belajar penting bagi siswa sekolah dasar. Motivasi belajar akan berdampak kepada kualitas pembelajaran, (Hamdu and Agustina, 2011). Oleh sebab itu guru harus mampu meningkatkan motivasi belajar siswa. Berdasarkan fakta-fakta tersebutlah diperlukan sebuah media pembelajaran yang dapat meningkatkan motivasi belajar siswa yang sesuai dengan karakteristik siswa sekolah dasar dan karekteristik era revolusi industri 4.0. Oleh sebab itu perlunya pengembangan multimedia interaktif menggunakan software macromedia flash 8 sebagai upaya meningkatkan motivasi belajar siswa sekolah dasar.

Setelah ditemukannya alasan utama pengembangan multimedia maka langkah selanjutnya adalah melakukan penganalisisan kurikulum. Analisis kurikulum bertujuan untuk mengetahui materi yang akan dikembangkan pada multimedia. Adapun materi yang digunakan pada pengembangan ini adalah tema 8 lingkungan sahabat kita, sub tema 1 manusia dan lingkungan. Adapun pemetaan kurikulum dapat dlihat pada gambar dibawah ini:

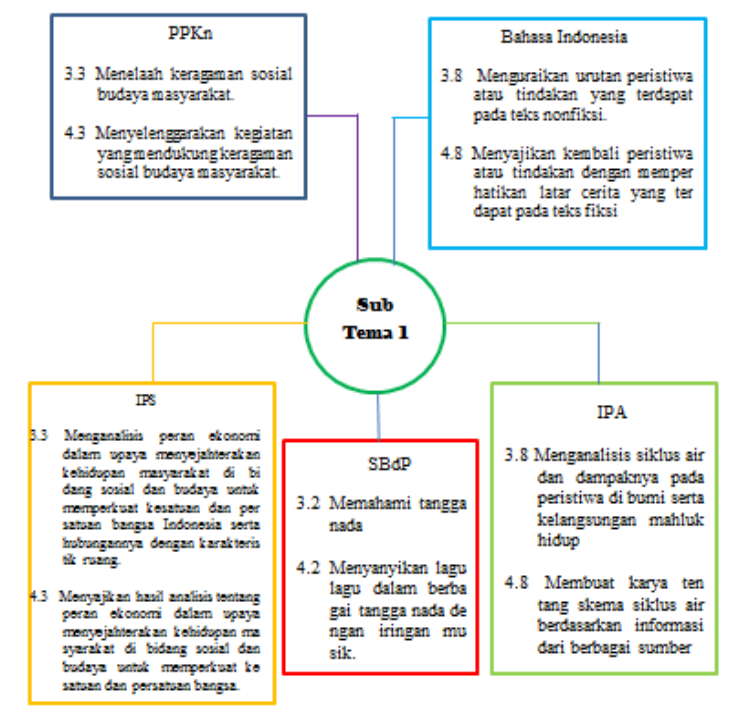

Gambar 1: Pemetaan Tema 
Berdasarkan gambar 1 penyajian tema tersebut maka dapat dilihat bahwa terdapt 5 pembelajaran yang dipadukan secara tematik.

Tahapan selanjutnya yaitu tahap perancangan. Pada tahapan ini terdapat dua kegiatan yaitu pembuatan flowchart dan pembuat strory board. Pembuatan flowchart bertujuan untuk memperlihatkan alur dan keterkaitan program yang dibuat. Adapun bentuk flowchart yang dibuat sebagai berikut:

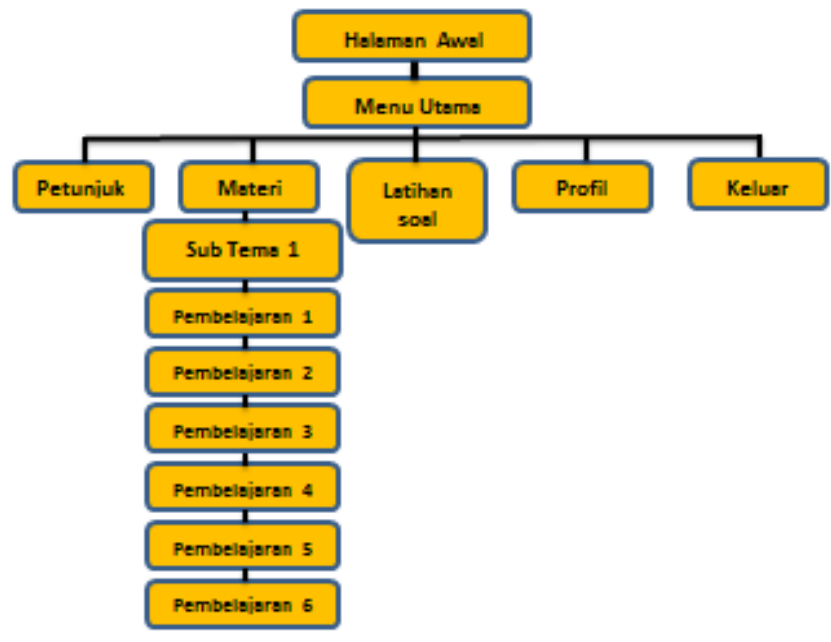

Gambar 2: Flowchart Multimedia Interaktif

Setelah pembuatan flowchart maka dilakuan pembuatan story board. Story board bertujuan untuk memmberikan informasi pada proses pengembangan multimedia. Adapun contoh storyboard sebagai berikut

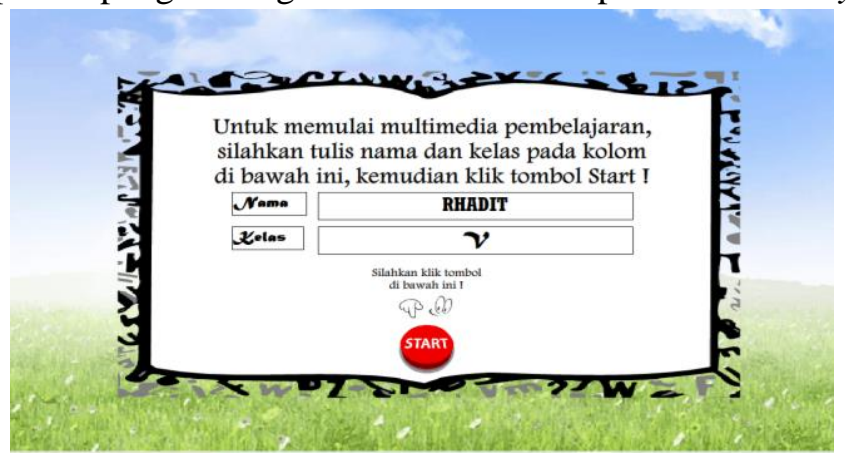

Gambar 3: Tampilan awal

Setelah dirancangnya flowchart dan storyboard maka selanjutnya dilakukan pengembangan multimedia interaktif menggunakan macromedia flash 8 . Setelah multimedia dikembangkan maka selanjutnya dilakukan validasi ahli. Validasi ahli bertujuan untuk menentukan kelayakan multimedia yang dikembangkan. Validasi ahli melibatkan 3 orang pakar yaitu validasi ahli media, validasi ahli materi dan validasi ahli bahasa.

Pada validasi media mendapatkan skor $82 \%$ dengan kategori valid namun terdapat beberapa revisi yang disarankan yaitu pada menu utama diharapkan diberikan kalimat perintah agar siswa jelas memahami intruksi yang diberikan, perlunya penambahan tombol navigasi, pengurangan kata-kata pada bagian bawah multimedia dan hindari penggunaan animasi yang berlebihan. Semua saran yang diberikan kemudian ditindak lanjuti agar dihasilkanya multimedia yang layak dari segi media. Validasi selanjutnya yaitu validasi materi. Validasi materi mendapatkan skor $87 \%$ dengan kategori valid namun terdapat beberapa revisi yang disarankan yaitu perlu disesuaikannya latar belakang dengan subtema dan perlunya penambahan tombol navigasi menuju KD, indikator, tujuan pembelajaran dan materi pembelajaran. 
Semua saran yang diberikan kemudian ditindaklanjuti agar dihasilkanya multimedia yang layak dari segi materi. Selanjutnya dilakukan validasi bahasa. Validasi bahasa mendapatkan skor $84 \%$ dengan kategori valid. Setalah semua saran pakar ahli ditindak lanjuti maka multimedia interaktif diujicobakan ke lapangan.

Uji coba kelapangan dilaksankan melalui tahapan penerapan. Pada tahapan penerapan ini dilakukan uji coba multimedia interaktif yang telah dinyatakan layak untuk diterapkan oleh pakar ahli. Pada uji coba ini dilakukan uji praktikalitas dan uji efektivitas. Uji praktikalitas bertujuan untuk mengetahui kepraktisan multimedia yang dikembangkang. Uji praktikalitas ini ditinjau dari aspek guru dan aspek siswa. Kepraktisan pada aspek guru mendapatkan skor sebesar $89 \%$ dengan kategori sangat praktis. Sehingga dapat disimpulkan bahwa multimedia interaktif dinyatakan praktis baik ditinjau dari aspek guru maupun aspek siswa.

Selanjutnya dilakukan uji efektivitas. Uji efektivitas bertujuan untuk melihat adanya peningkatan motivasi belajar siswa sebelum dan sesudah penggunaan multimedia interaktif. Hasil perhitungan motivasi belajar siswa mendapatkan skor rata-rata 84 dengan kriteria sangat tinggi. Hal ini membutikan bahwa adanya peningkatan motivasi belajar siswa sesudah penggunaan multimedia interaktif yang motivasi belajar awal mendapatkan skor 54 menjadi 84. Adapun peningkatan tersebut dapat dilihat pada grafik dibawah ini:

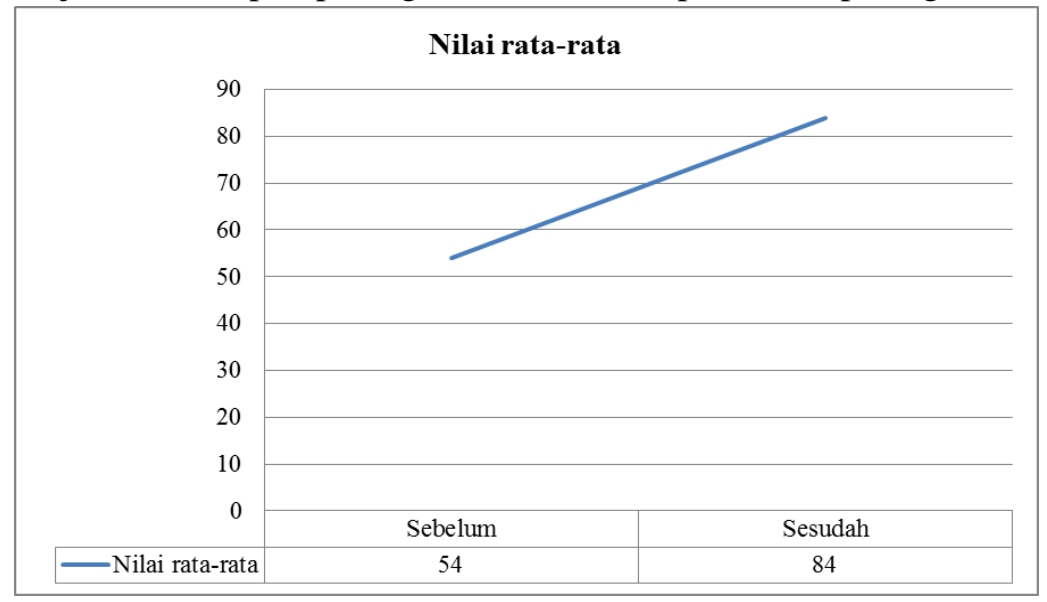

Gambar 4: Peningkatan skor motivasi belajar siswa

Dari gambar 4 tersebut dapat terlihat bahwa adanya peningkatan motivasi belajar siswa sekolah dasar dari sebelum penggunaan multimedia interaktif.

Multimedia interaktif merupakan media yang mengabungkan bebarapa unsur media seperti audio, vidio, teks, gambar, grafis dan animasi, (Novitasari, 2016). Multimedia ini dikembangkan dengan bantuan aplikasi macromedia flash. Macromedia flash merupakan sebuah program perancangan animasi yang diperuntukan untuk mendesain halaman web, game dan presentasi yang bersifat interaktif, (Maskur et al, 2017). Penelitian ini menyatakan bahwa multimedia yang dikembangan valid, praktis dan efektif. Kevalidan multimedia ini ditinjau dari 3 aspek yaitu aspek media, materi dan bahasa. Hal ini selaras dengan pernyataan bahwa media valid adalah media yang layak ditinjau dari aspek media, materi dan bahasa, (Putri et al, 2019).

Pada aspek media, multimedia yang dikembangkan memperhatikan kelayakan isi yang sesuai dengan perkembangan siswa sekolah dasar. Multimedia interaktif yang dikembangkan memperhatikan kemudahan siswa dalam menggunakannya. Selain itu juga diperhatikan warna teks, warna tampilan, gambar yang dipilih, audio/ vidio yang digunakan, serta animasi yang dapat meningkatkan semangat siswa. Hal ini selaras dengan pendapat yang menyatakan bahwa media yang valid adalah media yang memperhatikan kelayakan isi nya, (Hidayat et al, 2015; Rizal and Walidain, 2019). Selain itu multimedia ini dikembangkan dengan memperhatikan desan dan tata layout seperti pendesaian dan penempatan konten yang proposional agar kualitas tampilan lebih menarik. Selain itu juga diperhatikan pemilihan warna yang menarik, jenis dan ukuran tulisan. Kualitas backsound dan video juga menjadi perhatian khusus peneliti agar suara dan video yang 
791 Pengembangan Multimedia Interaktif Menggunakan Software Macromedia Flash 8 Sebagai Upaya Meningkatkan Motivasi Belajar Siswa Sekolah Dasar - Rahmad Wahyugi, Fatmariza

DOI: https://doi.org/10.31004/edukatif.v3i3.439

dihasilkan lebih jelas. Hal ini selaras dengan pendapat yang yang menyatakan bahwa media yang valid adalah media yang memperhatikan tata letak yang menarik, (Mukti and Nurcahyo, 2017; Anto et al, 2017).

Pada aspek materi pembelajaran pada pengembangan multimedia interaktif ini memperhatikan kesesuaian materi dengan tujuan pembelajaran. Selain itu materi disajikan secara sistematis dengan alokasi waktu yang tepat. Hal ini selaras dengan pendapat yang menyatakan bahwa media yang valid adalah media yang sesuai dengan tujuan pembelajaran yang telah ditetapkan, (Falahudin, 2014; Nurita, 2018). Pada aspek bahasa, pengembangan multimedia interaktif ini memperhatikan susunanan bahasa yang sederhana dan mudah dipahami oleh siswa. Hal ini selaras dengan pernyataan bahwa media pembelajaran yang valid yaitu media yang memperhatikan susunan bahwa yang sesuai dengan perkembangan siswa,(Purwanto, 2013).

Selain dinyatakan valid dan layak digunakan. Multimedia in juga dinyatakan praktis baik dari aspek siswa maupun aspek guru. Hal ini dikarenaka dalam pengembangan multimedia memperhatikan aspek kualitas isi dan tujuan seperti tujuan pembelajaran dan petunjuk penggunaan jelas serta isi materi sesuai dengan kompetensi dasar. Hal ini selaras dengan pendapat bahwa media yang praktis adalah media yang memperhatikan kualitas isi dan tujuan, (Salam, 2015). Selain itu multimedia ini juga memperhatikan kualitas teknis seperti kualitas suara, animasi, tampilan media, warnan tulisan yang disajikan dengan jelas serta menggunakan kalimat yang mudah dipahami. Hal ini selaras dengan pernyataan bahwa media yang praktis merupakan media yang memperhatikan apsek teknis penggunaan,(Mustaqim, 2017).

Temuan penelitian ini juga menyatakan bahwa multimedia yang dikembangkan juga dinyatakan efektif dalam meningkatkan motivasi belajar siswa sekolah dasar. Hal ini dikarenakan pada pengembangan multimedia interaktif dikembangkan dengan memperhatikan aspek perkembangan siswa. Sehingga siswa memiliki ketertarikan lebih terhadap penggunaan media sehingga dapat meningkatkan motivasi belajar. Hal ini selaras dengan pendapat bahwa media pembelajaran harus disesuaikan dengan tingkat perkembangan siswa, (Abi hamid et al, 2020). Selain itu multimedia ini juga dikembangkan dan digunakan dengan pemanfaatan teknologi seperti laptop maupun smartphone. Penggunaan teknologi seperti membuat siswa menjadi tertarik dalam melaksanakan proses pembelajaran. Hal ini selaras dengan pendapat yang menyatakan bahwa penggunaan teknologi dalam proses pembelajaran dapat meningkatkan kualitias pembelajaran, (Wolfson et al, 2014).

Temuan ini menyatakan bahwa telah dikembangkannya multimedia interaktif dengan menggunakan software macromedia flash 8 dalam meningkatkan motivasi belajar siswa sekolah dasar. Temuan ini membuktikan bahwa media pembelajaran dengan memadukan unsur teknologi dapat meningkatkan kualitas pembelajaran. Penelitian ini dapat dijadikan sebagai referensi bagi praktisi pendidikan terutama pada tingkatan sekolah dasar dalam upaya meningkatkan motivasi belajar siswa melalui pengembangan media pembelajaran berbasis teknologi. Namun penelitian memiliki keterbatasan karena dikembangkan pada satu sub tema kelas V saja. Perlunya penelitian lebih lanjut agar temuan penelitian menjadi lebih valid.

\section{KESIMPULAN}

Berdasarkan temuan penelitian dinyatakan bahwa telah dikembangkannya multimedia interaktif menggunakan software macromedia flash 8 sebagai upaya meningkatkan motivasi belajar siswa sekolah dasar yang valid, praktis dan efektif. Penelitian ini membutktikan bahwa penggunaan teknologi dalam proses pembelajaran dapat meningkatkan motivasi belajar siswa. Implikasi penelitian ini dapat dijadikan sebagai referensi oleh praktisi pendidikan untuk dapat meningkatkan motivasi belajar siswa. 
792 Pengembangan Multimedia Interaktif Menggunakan Software Macromedia Flash 8 Sebagai Upaya Meningkatkan Motivasi Belajar Siswa Sekolah Dasar - Rahmad Wahyugi, Fatmariza

DOI: https://doi.org/10.31004/edukatif.v3i3.439

\section{UCAPAN TERIMA KASIH}

Ucapan terimakasih kepada Universitas Negeri Padang yang telah memberikan izin terhadap pelaksanaan penelitian ini.

\section{DAFTAR PUSTAKA}

Abi Hamid, M., Ramadhani, R., Masrul, M., Juliana, J., Safitri, M., Munsarif, M., ... \& Simarmata, J. (2020). Media Pembelajaran. Jakarta: Yayasan Kita Menulis.

Afandi, R. (2015). Pengembangan media pembelajaran permainan ular tangga untuk meningkatkan motivasi belajar siswa dan hasil belajar IPS di sekolah dasar. JINoP (Jurnal Inovasi Pembelajaran), 1(1), 77-89.

Anto, P., Andrijanto, M. S., \& Akbar, T. (2017). Perancangan buku pedoman umum ejaan bahasa Indonesia sebagai media pembelajaran di sekolah. Jurnal Desain, 4(02), 92-99.

Azimi, A., Rusilowati, A., \& Sulhadi, S. (2017). Pengembangan Media Pembelajaran IPA Berbasis Literasi Sains untuk Siswa Sekolah Dasar. PSEJ (Pancasakti Science Education Journal), 2(2), 145-157

Batubara, H. H., \& Ariani, D. N. (2019). Model Pengembangan Media Pembelajaran Adaptif di Sekolah Dasar. Muallimuna: Jurnal Madrasah Ibtidaiyah, 5(1), 33-46.

Falahudin, I. (2014). Pemanfaatan media dalam pembelajaran. Jurnal Lingkar Widyaiswara, 1(4), 104-117.

Gadbury-Amyot, C. C., Singh, A. H., \& Overman, P. R. (2013). Teaching with technology: learning outcomes for a combined dental and dental hygiene online hybrid oral histology course. Journal of dental education, 77(6), 732-743.

Hamdu, G., \& Agustina, L. (2011). Pengaruh motivasi belajar siswa terhadap prestasi belajar IPA di sekolah dasar. Jurnal penelitian pendidikan, 12(1), 90-96.

Hamimah, H., Arlis, S., Arwin, A., Chandra, C., Anita, Y., Kenedi, A. K., \& Kharisma, A. (2019). Thinking the most convenient analysis of alpha generation by using social science story digital books. Elementary Education Online, 19(1), 78-86.

Helsa, Y. Y., Helsa, Y., Ariani, Y., \& Kenedi, A. K. (2019, December). Digital Class Model in Mathematics Learning in Elementary School Using Social Learning Network Schoology. In 5th International Conference on Education and Technology (ICET 2019) (pp. 739-742). Atlantis Press.

Helsa, Y. Y., Helsa, Y., Ariani, Y., \& Kenedi, A. K. (2019, December). Digital Class Model in Mathematics Learning in Elementary School Using Social Learning Network Schoology. In 5th International Conference on Education and Technology (ICET 2019) (pp. 739-742). Atlantis Press.

Helsa, Y., \& Kenedi, A. K. (2019). Edmodo-Based Blended Learning Media in Learning Mathematics. Journal Of Teaching And Learning In Elementary Education (JTLEE), 2(2), 107-117.

Hicks, S. D. (2011). Technology in today's classroom: Are you a tech-savvy teacher?. The Clearing House: A Journal of Educational Strategies, Issues and Ideas, 84(5), 188-191.

Hidayat, A., Saputro, S., \& Sukardjo, J. S. (2015). Pengembangan media pembelajaran ensiklopedia hukumhukum dasar kimia untuk pembelajaran kimia kelas X SMAN 1 Boyolali dan SMAN 1 Teras. Jurnal Pendidikan Kimia, 4(2), 47-56.

Kenedi, A. K., Ahmad, S., Sofiyan, T. A. N., \& Helsa, Y. (2019). The Mathematical Connection Ability of Elementary School Students in the 4.0 Industrial Revolution Era. International Journal of Innovation, Creativity and Change, 5(5), 458-472.

Kenedi, A. K., Eliyasni, R., \& Fransyaigu, R. (2019, December). Jigsaw using animation media for elementary school. In Journal of Physics: Conference Series (Vol. 1424, No. 1, p. 012027). IOP Publishing. 
793 Pengembangan Multimedia Interaktif Menggunakan Software Macromedia Flash 8 Sebagai Upaya Meningkatkan Motivasi Belajar Siswa Sekolah Dasar - Rahmad Wahyugi, Fatmariza

DOI: https://doi.org/10.31004/edukatif.v3i3.439

Kiswanto, A. (2017, September). The effect of learning methods and the ability of students think logically to the learning outcomes on natural sciences of grade ivs student. In 9th International Conference for Science Educators and Teachers (ICSET 2017) (pp. 1040-1046). Atlantis Press.

Lee, S. J., Srinivasan, S., Trail, T., Lewis, D., \& Lopez, S. (2011). Examining the relationship among student perception of support, course satisfaction, and learning outcomes in online learning. The Internet and Higher Education, 14(3), 158-163.

Lin, M. H., \& Chen, H. G. (2017). A study of the effects of digital learning on learning motivation and learning outcome. Eurasia Journal of Mathematics, Science and Technology Education, 13(7), 35533564 .

Mukti, I. N. C., \& Nurcahyo, H. (2017). Pengembangan media pembelajaran biologi berbantuan komputer untuk meningkatkan hasil belajar peserta didik. Jurnal Inovasi Pendidikan IPA, 3(2), 137-149.

Mustaqim, I. (2017). Pengembangan media pembelajaran berbasis augmented reality. Jurnal Edukasi Elektro, 1(1), 1-10

Naik, G., Chitre, C., Bhalla, M., \& Rajan, J. (2020). Impact of use of technology on student learning outcomes: Evidence from a large-scale experiment in India. World Development, 127, 104736.

Novitasari, D. (2016). Pengaruh penggunaan multimedia interaktif terhadap kemampuan pemahaman konsep matematis siswa. FIBONACCI: Jurnal Pendidikan Matematika Dan Matematika, 2(2), 8-18.

Nurrita, T. (2018). Pengembangan media pembelajaran untuk meningkatkan hasil belajar siswa. MISYKAT: Jurnal Ilmu-ilmu Al-Quran, Hadist, Syari'ah dan Tarbiyah, 3(1), 171.

Pratama, F., Firman, F., \& Neviyarni, N. (2019). Pengaruh Motivasi Belajar Siswa Terhadap Hasil Belajar IPA Di Sekolah Dasar. Edukatif: Jurnal Ilmu Pendidikan, 1(3), 280-286.

Pratiwi, S. I., Kristen, U., Wacana, S., Salatiga, K., \& Tengah, J. (2020). Pengaruh ekstrakurikuler pramuka terhadap karakter disiplin siswa sd. Edukatif: Jurnal Ilmu Pendidikan, 2(1), 62-70.

Pucer, P., Trobec, I., \& Žvanut, B. (2014). An information communication technology based approach for the acquisition of critical thinking skills. Nurse education today, 34(6), 964-970.

Putri, R. M., Risdianto, E., \& Rohadi, N. (2019). Pengembangan Media Pembelajaran Interaktif dengan Menggunakan Adobe Captivate Pada Materi Gerak Harmonik Sederhana. Jurnal Kumparan Fisika, 2(2), 113-120.

Rizal, S., \& Walidain, B. (2019). Pembuatan Media Pembelajaran E-Learning Berbasis Moodle Pada Matakuliah Pengantar Aplikasi Komputer Universitas Serambi Mekkah. JURNAL ILMIAH DIDAKTIKA: Media Ilmiah Pendidikan dan Pengajaran, 19(2), 178-192.

Salam, A. D. (2015). Pengembangan media pembelajaran berbasis web interaktif (blog) untuk meningkatkan motivasi belajar pada mata pelajaran pemasaran online sub kompetensi dasar merancang website (studi pada siswa kelas X tata niaga SMK Negeri 2 Nganjuk). Jurnal Pendidikan Tata Niaga (JPTN), 3(2), 1-10

Suhana, N. H. dan C. (2012). Konsep Strategi Pembelajaran. Bandung: PT Refika Aditama

Wolfson, N. E., Cavanagh, T. M., \& Kraiger, K. (2014). Older adults and technology-based instruction: Optimizing learning outcomes and transfer. Academy of Management Learning \& Education, 13(1), 2644. 